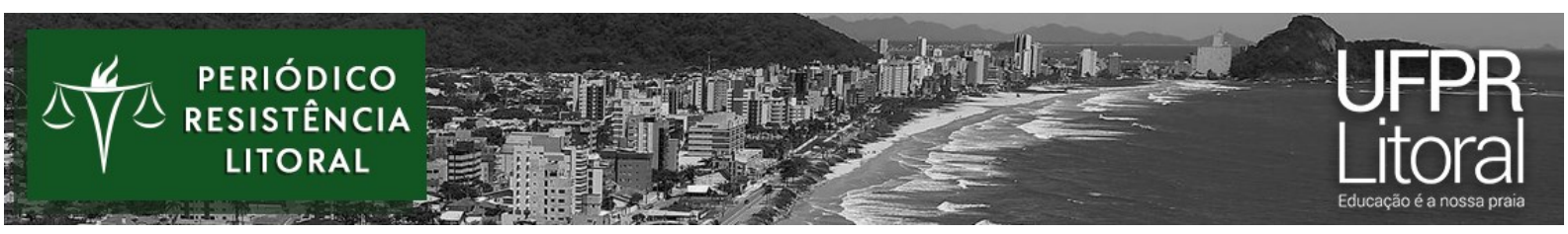

\title{
OS CONSELHOS MUNICIPAIS DE ASSISTÊNCIA SOCIAL: análise de sua constituição e organização
}

\author{
Fabiana Luiza Negri ${ }^{1}$ - Universidade Federal de Santa Catarina \\ Laine Motter de Oliveira ${ }^{2}$ - Universidade Federal de Santa Catarina
}

\section{RESUMO}

Este artigo tem por objetivo caracterizar a organização dos Conselhos Municipais de Assistência Social (CMAS), identificando a participação da sociedade civil. Aborda-se a problematização das políticas sociais, do Estado e da sociedade civil, perpassando pela assistência social e pelo conceito de controle social. As principais referenciais teóricas utilizadas foram Gramsci, Bravo, Iamamoto e Raichelis. A metodologia pautou-se na teoria social crítica a partir apreensão da totalidade, elaborando mediações da realidade e suas contradições. Trata-se de uma pesquisa de abordagem qualitativa, partindo do estudo bibliográfico e do estudo exploratório sobre os CMAS de 36 municípios das 06 Mesorregiões de Santa Catarina. No estudo exploratório observou-se que os conselhos são, em sua maioria, compostos por representações paritárias entre sociedade civil e esfera governamental, no entanto, constataram-se também disparidades nas representações. Outro achado foi o baixíssimo acesso às informações acerca dos conselhos, resultando numa fraca transparência dos municípios sobre o controle social.

Palavras-chave: Conselho Municipal de Assistência Social. Controle Social. Assistência Social.

\section{ABSTRACT}

This article aims to characterize the organization of Municipal Councils for Social Assistance (CMAS), identifying the participation of civil society. It addresses the problematization of social, State and civil society policies, passing through social assistance and the concept of social control. The main theoretical references used were Gramsci, Bravo, Iamamoto and Raichelis. The methodology was based on critical social theory from the apprehension of the totality, elaborating mediations of reality and its contradictions. This is a research with a qualitative approach, based on a bibliographic study and an exploratory study on the CMAS of 36 municipalities in the 06 Mesoregions of Santa Catarina. In the exploratory study, it was observed that councils are mostly composed of equal representations between civil society and the governmental sphere, however, there were also differences in representations. Another finding was the very low access to information about the councils, resulting in poor transparency of the municipalities on social control.

Keywords: Municipal Council for Social Assistance. Social Control. Social assistance.

\footnotetext{
1 - Doutora em Serviço Social - professora do curso de Serviço Social da Universidade Federal de Santa Catarina - e-mail: fabianaluizanegri@yahoo.com.br

2 - Discente em Serviço Social pela Universidade Federal de Santa Catarina. motterlaine@gmail.com
} 


\section{INTRODUÇÃO}

O presente trabalho tem origem na pesquisa desenvolvida no Curso de Graduação em Serviço Social da Universidade Federal de Santa Catarina sob o título: "Os Conselhos Municipais de Assistência Social: a atuação do/a assistente social e o processo de participação democrática", a qual tem por objetivo caracterizar e analisar a intervenção profissional do/a assistente social no âmbito dos conselhos municipais de assistência social de Santa Catarina, identificando suas estratégias para a consolidação da participação democrática da sociedade civil. Vale destacar que se trata de uma pesquisa contemplada com bolsa PIBIC/CNPQ 20202021, garantindo assim a participação de discente do Curso de Serviço Social como bolsista.

Aqui se apresentam os resultados da segunda fase da pesquisa proposta, a partir de um estudo exploratório, de análise documental realizada no período de novembro de 2020 a abril de 2021, cuja finalidade é identificar e caracterizar a organização dos Conselhos Municipais de Assistência Social (CMAS), buscando reconhecer a participação da sociedade civil e o seu perfil.

O estudo exploratório se desenvolveu através da busca das Leis de Criação dos Conselhos e das Portarias de Nomeação dos conselheiros, por meio dos Sites de 36 municípios catarinenses, as quais passaram por uma compilação das informações e análises aqui apresentadas, tratando-se de um estudo de abordagem qualitativa, por intermédio de uma pesquisa documental.

O tema central desse trabalho é a organização e formação dos conselhos municipais de assistência social, pois assim é possível identificar os representantes da sociedade civil, traçando seu perfil, a fim de caracterizar a participação e as correlações de forças presentes no interior destes conselhos.

A pesquisa emerge num contexto em que os espaços de controle social estão em permanente processo de investidas para sua desregulamentação, dado o acirramento da agenda ultraneoliberal, que busca a desconstrução sistemática dos espaços de participação democrática e desmonte de políticas sociais com a regressão dos direitos sociais historicamente conquistados pela classe trabalhadora. 


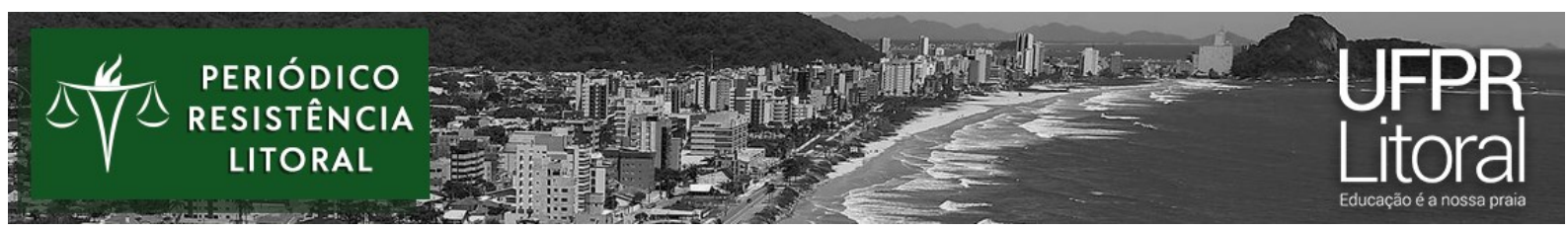

O controle social surge no contexto da Constituição Federal de 1988, onde a Carta Magna propõe em seu artigo 204, alínea II - "participação da população, por meio de organizações representativas, na formulação das políticas e no controle das ações em todos os níveis", ou seja, a garantia de participação democrática da sociedade civil tanto na formulação de políticas como no seu controle para efetivação dos interesses dos usuários. Nesse mesmo viés, a Lei Orgânica da Assistência Social de 1993, atualizada pela Lei 12.435/2011 diz em seu artigo $6^{\circ}$, parágrafo $2^{\circ}$ “O Suas é integrado pelos entes federativos, pelos respectivos conselhos de assistência social e pelas entidades e organizações de assistência social abrangidos por essa Lei”. Portanto, compõem o SUAS tanto os órgãos gestores governamentais de todas as esferas como os órgãos de controle social com a participação de representantes da sociedade civil, possibilitando uma gestão democrática da política. Igualmente o artigo 17 parágrafo $4^{\circ}$ institui que "os conselhos [...] tem competência para acompanhar a execução da política de assistência social, apreciar e aprovar a proposta orçamentária em consonância com as diretrizes das conferências", evidenciando que o controle social é exercido pela sociedade civil nas ações desenvolvidas pelo Estado.

No entanto, o processo histórico de implementação da política de assistência social e, por consequência, dos conselhos, tem demonstrado que este espaço passa por dificuldades na relação Estado-sociedade civil, no sentido de se sobressair em ultima análise, a descaracterização do controle da sociedade sobre as ações estatais e, ultimamente, há uma forte incidência para reduzir o espaço da sociedade civil, comprometendo a participação democrática assegurada nas legislações. É notório que mesmo em tempos de avanços da política de assistência social, especialmente nos governos Luiz Inácio e Dilma, o Estado brasileiro teve dificuldades em dar respostas adequadas e encaminhamentos efetivos às demandas da classe trabalhadora, ainda que tenham construído programas, projetos, serviços e benefícios que consolidaram uma série de direitos, mas em grande medida, insuficientes diante da desigualdade social histórica do país.

No contexto atual, o capital financeiro adentra em todas as esferas da vida social, apropriando-se, com uma fome voraz, de tudo que é público, acirrando a intensificação da exploração da força de trabalho com enorme extração de mais-valia, promovendo o crescimento do trabalho precarizado e desprotegido, o subemprego e aprofundando o desemprego, impactando diretamente na capacidade de produção e elevando a acumulação de capital fictício, assim como capturando o Estado, o qual tem permitido sua reprodução e garantido seus lucros 
(IAMAMOTO, 2019). Nessa conjuntura, as políticas sociais tornam-se "favorecedoras da esfera financeira e do grande capital produtivo - das instituições e dos mercados financeiros difundidas pelos organismos multilaterais [...]" (IAMAMOTO, 2019, p. 18).

Desse modo, a inflexão da política de assistência social, resulta da agenda de políticas neoliberais, onde a prioridade é estabelecer parcerias público/privado desresponsabilizando o Estado na sua implementação e atribuindo as organizações não governamentais o papel de gestão da política pública, afetando as relações Estado-sociedade civil no âmbito do controle social.

Diante deste cenário, a análise e reflexão sobre a relação Estado-sociedade civil, políticas sociais e o controle social são necessários para elaborarmos conteúdo e posicionamento críticos acerca da realidade concreta, a fim de construir estratégias de resistência e enfrentamento.

Para tanto, o artigo ora apresentado está dividido em três partes, a primeira trata da apreensão da relação entre Estado-sociedade civil e seus conceitos, busca construir reflexões acerca das políticas sociais tanto na sua concepção como na sua execução mediante uma agenda política neoliberal, chegando às reflexões sobre a política de assistência social, com foco para a questão do controle social.

A segunda parte apresenta-se brevemente o caminho metodológico do estudo exploratório realizado, do qual resultaram as análises aqui traçadas. Na terceira parte elaboramse reflexões sobre os conselhos de assistência social sua concepção e apresentam-se as informações e resultados obtidos na pesquisa documental, demonstrando a composição, organização dos CMAS e o perfil dos representes dos conselhos.

Por fim, tecemos algumas considerações finais, que apontam para a importância do controle social e a necessidade de estratégias de resistência com o objetivo de garantir a participação democrática da sociedade civil, diante de um contexto atual de desmonte, assim como se demonstram as correlações de forças presentes e o perfil preponderante destes espaços, o que desvela que se trata de um espaço em disputa, que envolve a defesa das demandas da classe trabalhadora.

\section{POLÍTICAS SOCIAIS, ESTADO E SOCIEDADE CIVIL E O CONTROLE SOCIAL}




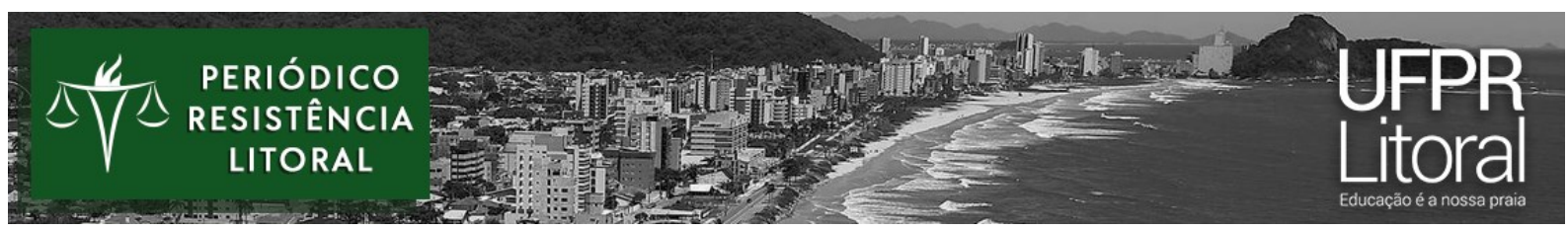

O Estado burguês, mantendo e sustentando a ordem capitalista e os interesses da burguesia, reproduz as condições de submissão da classe trabalhadora aos interesses do capital. Nesse sentido, busca conservar sua legitimidade e da mesma forma procura administrar as necessidades da classe subalterna e igualmente da ordem burguesa através da adesão que recebe das categorias e dos setores (NETTO, 2011, p. 30). Por conseguinte, as políticas sociais são estratégias elaboradas na mediação entre Estado e sociedade instituindo respostas as diversas expressões da questão social ${ }^{3}$ (RAICHELIS, 2015, p. 106), ou seja, situam-se na mediação das relações de classe, bem como estão condicionadas a uma relação contraditória, expressando conflitos de interesses e disputas, no movimento de correlação de forças entre Estado e sociedade civil.

Pelo ângulo econômico, as políticas sociais assumem a função de reduzir os custos da reprodução da força de trabalho e elevar a produtividade, bem como manter elevados níveis de demanda de consumo, em épocas de crise. Pelo ângulo político, as políticas sociais são vistas como mecanismos de cooptação e legitimação da ordem capitalista, pela via da adesão dos trabalhadores ao sistema. (BEHRING, 2008, p.37).

As políticas sociais devem ser compreendidas em seu caráter contraditório, ora servindo aos interesses do capital, ora aos interesses dos trabalhadores. Assim sendo, são elas que viabilizam uma rede de proteção social e ao mesmo tempo operam a manutenção da força de trabalho e instituem uma relação de apaziguamento e controle sobre a classe trabalhadora. Nessa perspectiva, de acordo com Raichelis (2015, p. 106, grifo nosso) “o sistema de proteção social apresenta elevado nível de fragmentação, carrega fortes traços de enquadramento seletivo das demandas sociais [...] e igualmente, responde a uma dada correlação de forças [...]”. Nessa lógica, é necessário compreender que o Estado como o operacionalizador das políticas sociais é um espaço de disputa de interesses das classes antagônicas.

O Estado aqui é compreendido como um espaço de construção de hegemonia diretamente articulado com a sociedade civil, o que Gramsci define como Estado Integral. Para Gramsci (2005, p. 84), “[...] o conceito de Estado restrito é entendido como sociedade política (ou ditadura, ou aparelho coercitivo, para moldar a massa popular segundo o tempo de produção

\footnotetext{
${ }^{3}$ Resultado da contradição capital x trabalho, emergindo com a origem e a expansão do pauperismo da classe trabalhadora, expressando-se com as desigualdades sociais, econômicas, políticas e culturais. Conforme Iamamoto (1991, p. 77), a questão social são as expressões do processo de surgimento e de desenvolvimento da classe operária e de sua introdução no cenário político, exigindo reconhecimento como classe por parte do Estado e do empresariado, manifestando-se enquanto a contradição entre o proletariado e a burguesia.
} 
e a economia de um dado momento)." Entretanto, o autor afirma que o conceito de Estado vai adquirindo as novas características do capital monopolista do século XX, permitindo entender “a relação unidade-distinção entre Estado e sociedade civil - relação apenas metodológica e não orgânica” (GRAMSCI 2011, p. 257), ou seja, o Estado torna-se ampliado ou integral na medida em que vai se articulando com os aparelhos privados de hegemonia na construção de sua legitimidade e defesa dos interesses burgueses o que mantem seu caráter classista e repressivo, mas abarca igualmente a dimensão da criação de consensos. Nesse viés, aqui se referencia o conceito de sociedade civil, fundamentado em Gramsci (2010, p. 20-21), que diz tratar-se de "[...] um conjunto de organismos designados vulgarmente como privados [...] plano que corresponde à função de hegemonia que o grupo exerce em toda a sociedade e àquela de domínio direto ou de comando, que se expressa no Estado e no governo jurídico.” A sociedade civil, nesse sentido, exerce a função de formação de consensos em torno dos interesses classistas, sendo espaço da luta de classes, da disputa pela hegemonia e pela conquista do poder político pela classe subalterna (FERRAZ; RABELO; HERKENHOFF, 2010, p. 96).

Desse modo, o Estado tem a função de garantir proteção social, porém, como “um organismo próprio de um grupo, destinado a criar as condições favoráveis à expansão máxima desse grupo [...]", ainda que desenvolva seu papel de criação de consensos, através, por exemplo, das políticas sociais, sempre estará atrelado aos interesses da classe dominante, cujo objetivo é "coordenar os interesses dos grupos subordinados" (GRAMSCI, 2011, p. 41). Assim sendo, a relação Estado-sociedade civil sempre está amalgamada por relações ora de coerção, ora de consenso na construção da legitimidade dos grupos dominantes.

Na realidade brasileira nas palavras de Raichelis (2015, p. 113), “a Nova República herdou um quadro social dramático do regime autoritário do que se originou uma série de planos emergenciais e as reformas estruturais foram remetidas à Assembleia Constituinte", assim a relação Estado-sociedade civil foi também se moldando a partir da Carta Magna, com a implementação de reformas que direcionaram política, econômica e socialmente o país.

Nessa esteira ocorreu a instituição do controle social, a partir da Constituição Federal de 1988, em que os conselhos de políticas sociais tinham como prerrogativa o controle e fiscalização das ações estatais pela sociedade civil, tanto no âmbito da elaboração de propostas para implementação, quanto no âmbito da operacionalização. Contudo, o processo histórico desvela a construção de relações fragilizadas e esses espaços assumem características meramente cartorárias, afastando-se do previsto inicialmente. 


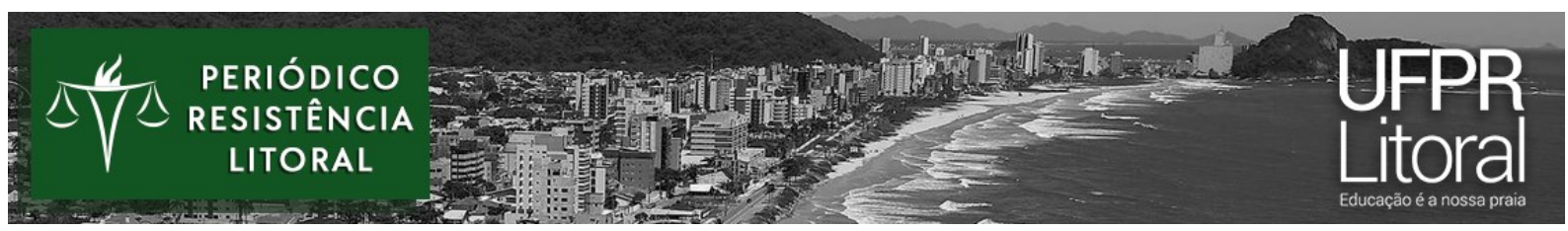

O controle social, nesse momento, é inscrito na Constituição de 1988, enfatizando a participação democrática dos setores organizados da sociedade civil, principalmente dos segmentos populares, na tentativa de criar novas relações entre os movimentos sociais e a esfera da política institucional (RAICHELIS, 2008, p. 21). Por outro lado, de acordo com Machado (2015, p. 24), o que a Constituição Federal vigente aborda são os princípios dessa participação social, entretanto, são as leis específicas de cada política pública que definiram como essa participação ocorreria nos espaços dos colegiados, dos conselhos e das conferências.

No cenário brasileiro, desde a década de 1990 tem-se o avanço das políticas neoliberais - no mesmo período em que os conselhos de políticas sociais foram instituídos -, buscando limitar as funções do Estado com o objetivo de sua privatização. Boschetti (2010, p. 83) relembra que há a tendência da privatização das políticas sociais, em busca da mercantilização dos serviços públicos como a educação, a saúde, a previdência social, para criar novos nichos de mercado. Nessa lógica, a política de assistência social também sofreu alterações, tanto no que diz respeito à sua execução, quanto no seu controle e fiscalização.

A Lei Orgânica de Assistência Social (LOAS), instituída em 1993, estabelece que os conselhos municipais constituem-se em uma das instâncias deliberativas do sistema descentralizado e participativo da assistência social, definindo a estrutura geral destes aos níveis nacional, estadual e municipal (ROCHA, 2008, p. 142).

Em 2003, com a IV Conferência Nacional de Assistência Social, demanda-se a implementação do Sistema Único de Assistência Social (SUAS), o qual propõe a gestão da política pela responsabilidade do Estado como também reforça a relação com a sociedade civil, emergindo o trabalho das entidades e instituições públicas não estatais. A Política Nacional de Assistência Social (2004), implementada pelo Ministério do Desenvolvimento Social e Combate à Fome, evidenciou a assistência social como direito de cidadania e responsabilidade do Estado. Nessa perspectiva, o SUAS determinou nova direção para a política de assistência social, fortalecendo sua gestão e implementando novos conceitos para o atendimento aos usuários, ressaltando uma proposta interventiva que valoriza o atendimento integral à família referenciada em determinado espaço territorial, utilizando uma rede socioassistencial.

Durante os governos petistas, o SUAS significou um grande avanço na gestão da política de assistência social, instituindo a profissionalização, a padronização, as concepções e conceitos da política de assistência social enquanto política pública e o protagonismo do usuário. Com o governo Temer, retoma-se o antigo assistencialismo e clientelismo, considerando o papel da 


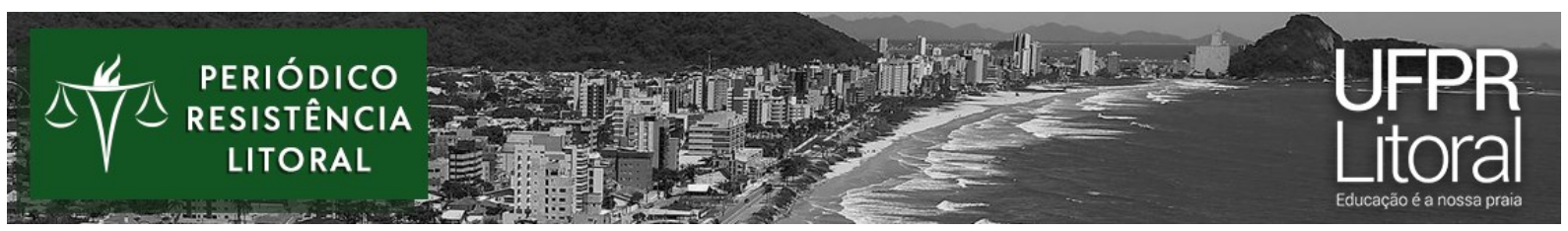

primeira-dama. Ademais, é importante relembrar que foi no governo Temer que a Emenda Constitucional $n^{\circ} 95 / 2016^{4}$ foi aprovada, congelando os gastos com políticas sociais por 20 anos. O atual governo, adotando políticas ultraneoliberais, vem promovendo um desmonte acelerado e contínuo que afeta diretamente os direitos sociais. Destaque para a Emenda Constitucional $n^{0} 103 / 2019^{5}$, que destrói o conceito de proteção social ${ }^{6}$ amplo e de cobertura universal, atropelando a Seguridade Social e agravando a desigualdade social. O Estado brasileiro mostra-se, historicamente, direcionado aos interesses do capital, materializando-os tanto através dos ataques aos direitos sociais como no processo de privatização. Mediante todas essas condições, são essenciais ações que estimulem a participação crítica da sociedade civil fortalecendo a luta e a garantia dos direitos.

No contexto de contrarreformas da atual conjuntura, está posta a necessidade de refletir e analisar os espaços de controle social, compreendendo que esses estão ameaçados pela desregulamentação. Partindo disso, os conselhos destacam-se, principalmente, enquanto estruturas do Estado, estabelecidos pela Constituição Federal de 1988, que ampliam a participação da sociedade civil na elaboração e na implementação de políticas públicas, objetivando a democracia participativa (BRONSTEIN; FONTES; PIMENTA, 2017, p. 01-02) e, nesse sentido, entende-se que é dever da estrutura da política pública de assistência social manter e estimular a participação dos cidadãos nesse espaço.

Os conselhos de políticas sociais constituem um importante espaço de democracia participativa e estão presentes nos municípios, nos estados e a nível federal. De acordo com o Munic/IBGE de 2001, há mais de 90\% dos municípios brasileiros que possuem conselhos (ALMEIDA; TATAGIBA, 2012, p. 69). Além disso, são órgãos de administração pública e têm poder deliberativo por um colegiado, são criados por lei federal, estadual ou municipal, no qual participam representantes estatais e da sociedade civil. Nesse sentido, constituem um espaço de disputa de interesses entre o poder público e a sociedade civil. É imprescindível considerar o avanço legal da instituição desses conselhos, entretanto, no âmbito político manifestam-se diversos desafios, na medida em que alguns conselhos apresentam Planos de Ação mal elaborados, outros possuem ações apenas burocráticas, sem preocupação com o efetivo controle

\footnotetext{
${ }^{4}$ A Emenda Constitucional $n^{\circ}$ 95/2016 congela por vinte anos as despesas primárias, onde estão inscritos os investimentos em políticas públicas.

${ }^{5}$ A Emenda Constitucional $n^{\circ}$ 103/2019 altera o sistema de previdência social.

${ }^{6}$ A proteção social consolida-se com a articulação de todas as políticas sociais que constituem a Seguridade Social - saúde, assistência social e previdência social - tal como pautada na Constituição Federal de 1988.
} 
social. Da mesma forma, observa-se ao longo do processo sócio-histórico de instituição dos conselhos, principalmente após avanço neoliberal, uma baixa capacitação dos conselheiros, a fragmentação das demandas, ausência de uma agenda programada, ausência de democracia e perda da concepção de totalidade das políticas públicas.

De outra parte, salienta-se que o controle social deve ser entendido na relação dialética entre o Estado que abrange a sociedade civil formada por interesses opostos, o qual se viabiliza na perspectiva da defesa dos interesses da classe subalterna (BRAVO; CORREIA, 2012, p. 134). Porém, é notória a linha adversa que tem tomado o controle social no Brasil, evidenciando uma fragilidade na relação do Estado com a sociedade, na medida em que não se constata a participação efetiva da sociedade civil nos espaços de participação democrática gerenciados pelo Estado, utilizando desses espaços para cumprir funções burocráticas, conforme apontam estudos ${ }^{7}$.

Diante desse contexto, a pesquisa exploratória elaborada investigou a composição e organização dos CMAS de trinta e seis municípios catarinenses, a qual apontou os primeiros indícios dos desafios da participação da sociedade civil no âmbito dos conselhos.

\section{CAMINHOS DA PESQUISA: O ESTUDO EXPLORATÓRIO}

A pesquisa desenvolvida fundamenta-se na perspectiva teórica marxista de leitura da realidade, parte de uma abordagem qualitativa ${ }^{8}$ e busca encontrar as respostas de como se configuram os conselhos municipais de assistência social? Quem são os representantes da sociedade civil? Para isso, realizou-se uma pesquisa nos Sites dos municípios, assim como foram contatados os profissionais que atuam na assessoria aos conselhos, a fim de identificar as Leis de criação destes conselhos e as Portarias de nomeação dos conselheiros.

O estudo exploratório desencadeou uma pesquisa documental, na qual se identificou as legislações pertinentes de cada município das seis Mesorregiões, a saber: Grande Florianópolis: Florianópolis, Antônio Carlos, Governador Celso Ramos, Tijucas, Santo Amaro da Imperatriz e São José; Vale do Itajaí: Blumenau, Bombinhas, Timbó, Porto Belo e Itapema; Sul Catarinense: Criciúma, Lauro Müller, Vidal Ramos, Garopaba, Imbituba, Braço do Norte

\footnotetext{
${ }^{7}$ Estudos de Krüger (2012), Tatagiba; Dagnino (2002), Tatagiba (2004), Fuks; Perissionotto; Souza (2004), e Raichelis (1998).

${ }^{8}$ Segundo Gondim (2003, p. 150), a abordagem qualitativa possibilita a compreensão de uma realidade particular, de autorreflexão, não havendo um fim em si mesmo, sendo um instrumento para auto conscientização e ação humana.
} 
e Tubarão. Norte Catarinense: Joinville, Garuva, Itapoá, São Francisco do Sul, São Bento do Sul e Guaramirim; Oeste Catarinense: Chapecó, Coronel Freitas, Águas de Chapecó, São Miguel do Oeste, Xaxim e Xanxerê e Mesorregião Serrana: Lages, Correia Pinto, Bocaina do Sul, Campos Novos, São Joaquim e Curitibanos.

Com a identificação das legislações passou-se a análise das informações coletadas, observando o perfil dos representantes da sociedade civil e a composição de cada conselho, buscando identificar se havia ou não uma relação paritária em sua formatação e as correlações de forças presentes.

\section{OS CONSELHOS DE ASSISTENCIA SOCIAL: UM ESPAÇO DE DISPUTAS}

No caso da política de Assistência Social, salienta-se a Lei Orgânica de Assistência Social (LOAS), de 1993 - aprovada mais de cinco anos após a promulgação da Constituição Federal de 1988 -, que caracteriza a participação da sociedade civil através das organizações representativas em todos os níveis e, posteriormente, com a Política Nacional de Assistência Social (PNAS 2004) reafirma essa participação e suas características com o Sistema Único de Assistência Social (SUAS).

Como dito anteriormente, os conselhos de políticas públicas começam a ser instituídos a partir da década de 1990, na mesma época em que o contexto político brasileiro era marcado pelo avanço da agenda neoliberal, pela fragilização dos movimentos sociais e enfraquecimento da organização da sociedade, demarcando, assim, alguns aspectos limitantes quanto à construção desses espaços democráticos naquela determinada conjuntura. É de suma importância destacar que os conselhos de políticas públicas são espaços de elaboração, deliberação, avaliação e fiscalização das políticas nas três esferas de governo (MACHADO, 2015, p. 24) e, nesse viés, constitui-se enquanto espaços de disputa política e de contradição, característicos da relação Estado-sociedade civil. Como nos coloca Bravo (2008, p. 59),

Os conselhos não podem nem ser supervalorizados, nem subvalorizados, apresentando como dificuldades: o desrespeito do poder público pelas deliberações dos conselhos; o não cumprimento das leis que regulamentam o seu funcionamento; a burocratização das ações; a não divulgação prévia da pauta das reuniões; a infraestrutura precária; a ausência de definição orçamentária; a falta de conhecimento da sociedade civil organizada sobre os conselhos; a ausência de articulação mais efetiva dos conselheiros com suas bases; a dificuldade dos conselheiros interferirem na dinâmica dos conselhos; a chantagem institucional do poder executivo, alegando que, caso as propostas apresentadas sejam questionadas pelos conselheiros, irá trazer 


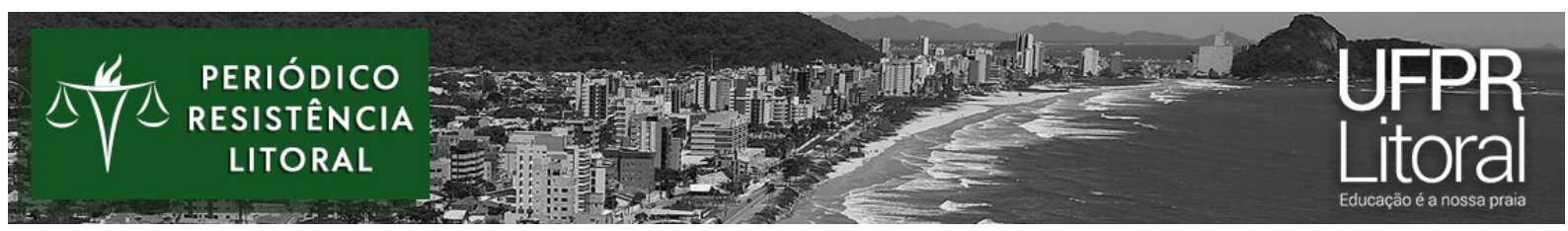

prejuízos para a população; a ausência de soluções jurídicas mais ágeis; a contribuição ainda incipiente dos conselhos para a democratização da esfera pública.

Os Conselhos Municipais de Assistência Social, nessa lógica, são atravessados pelos limites postos na relação Estado-sociedade, portanto fundamental compreende-los como parte da política pública em constante disputa. E para isso, é essencial que a sociedade civil, através dos movimentos sociais e da organização coletiva, possa construir suas estratégias e encontrem caminhos para o fortalecimento da sua representação, por meio da ampliação de sua participação, onde a democracia e os interesses coletivos estejam acima dos interesses meramente coorporativos e econômicos, como nos alerta GRAMSCI (2011, p. 41).

[...] dentro do limite do capital, tem o compromisso na defesa da universalização do direito, no protagonismo do usuário, na ampliação das políticas públicas e na fiscalização do fundo público. E isso só vai ser possível através do atrelamento ao movimento social. (MOREIRA, 2008, p. 69).

Como afirma a autora, não se pode desconsiderar o movimento do real concreto, inseridos no modo de produção capitalista, sendo necessário pensar e propor ações que materializem a disputa entre as classes antagônicas. Portanto, para compor um conselho de políticas sociais é preciso ter posicionamento ético-político crítico, compreender a disputa classista e manter posicionamento de resistência, donde a importância de termos nos conselhos representantes da sociedade civil que de fato tenham essa perspectiva.

$\mathrm{Na}$ análise das informações coletadas no estudo exploratório, através da pesquisa documental, a primeira observação constatada foi o fato de que as Leis e Portarias, que são documentos públicos, em parte dos municípios não estavam disponíveis e acessíveis à consulta popular. Assim, a primeira observação é que se demarca a ausência de transparência na socialização das informações pertinentes aos conselhos nos municípios pesquisados.

Nesse sentido, dos trinta e seis (36) municípios, onze (11) deles, ou seja, 30,5\% dos municípios não disponibilizam as informações acerca da criação e constituição dos conselhos, pelos meios de comunicação oficiais, porém vinte e cinco (25) municípios apresentaram as legislações nos sites dos municípios, garantindo acesso à informação.

Observa-se que há uma maioria que disponibiliza as informações básicas de existência e constituição dos CMAS, fato importante. Contudo, ainda há um número expressivo de municípios que não disponibilizam essas legislações de forma acessível, inclusive incorrendo em descumprimento à Lei de Acesso à Informação - Lei Federal nº 12.527 de 18/11/2011 -, 


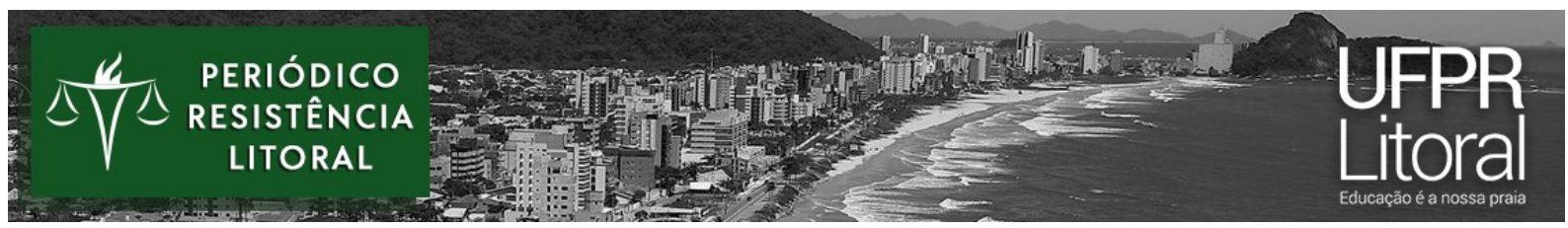

que tem por finalidade garantir o acesso à informações relativos aos órgãos públicos, as autarquias, as fundações públicas e sociedades de economia mista dos três níveis: municipal, estadual e federal. A ausência de publicidade impossibilita a sociedade civil de ter o conhecimento do próprio espaço de controle social.

A falta de informações e de dados localizada nos onze (11) municípios condiz, com algumas das problemáticas já sinalizadas anteriormente: a falta de conhecimento da sociedade civil sobre os conselhos, bem como a baixa contribuição dos conselhos para a democratização da esfera pública (BRAVO, 2008, p. 59). Para, além disso, Raichelis (2008, p. 25) é precisa ao questionar quais as condições concretas que os usuários possuem para participar da esfera pública das políticas sociais e, nesse cenário, considerando a indisponibilidade de informações básicas dos CMAS para com a sociedade civil, as condições mais precárias da participação e a representação dos usuários no espaço dos conselhos já se origina na ausência de informação. É notória a necessidade de fortalecimento da participação da sociedade civil nos espaços de participação democrática e, para tal, algumas estratégias podem ser tomadas, sendo fundamental que essas informações básicas estejam acessíveis.

Quanto à paridade 9 na formação dos conselhos, observam-se os seguintes dados: primeiramente, da totalidade de trinta e seis (36) CMAS, onze (11) destes não foram encontradas informações; dos vinte e cinco (25) restantes, três (03) deles não possuem paridade entre conselheiros governamentais e não governamentais e outros vinte e dois (22) são paritários. Cabe a ressalva: a representação não governamental não significa necessariamente que há uma efetiva representação da sociedade civil organizada organicamente, na medida em que se constata uma ampla representação de associações, entidades religiosas, sociedades culturais, que apresentam finalidades diversas da própria política de assistência social.

A falta de paridade, mesmo que em um número pequeno de municípios, está na contramão da proposta dos conselhos de políticas públicas constante na Constituição Federal de 1988, na LOAS (1993) e na PNAS (2004), não deveria ocorrer em nenhum município, pois essa situação se contrapõe ao que está previsto em todas as legislações. De acordo com Bronstein, Filho, Pimenta (2017, p. 90),

\footnotetext{
${ }^{9}$ Isto é, a igualdade no número de representações governamentais e não governamentais nos CMAS. A paridade é estabelecida pelo Art. $16^{\circ}$ da Lei Orgânica de Assistência Social (LOAS), de 1993, no âmbito das três esferas da federação, entretanto, a mesma não pode ferir a autonomia dos entes federados (SANTOS, 2016, p. 14).
} 


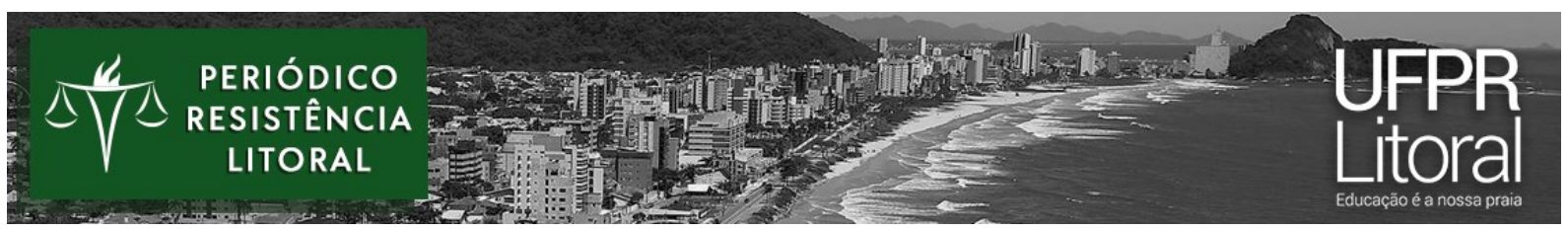

Uma adequada estrutura de governança dos conselhos deve ser capaz de estimular a participação dos cidadãos. [...] Entende-se por governança nesse contexto a adoção de regras claras de deliberação, accountability, controle externo efetivo, equidade de direitos de participação de membros e dos cidadãos, capacidade de refletir e discutir os problemas da sociedade, não restringindo o debate a um grupo de atores influentes ou do governo.

A disparidade mostra, nesse sentido, a falha na estrutura e no funcionamento dos conselhos. A ausência de paridade implica diretamente na materialização dos interesses de grupos econômicos ou interesses particulares em detrimento dos interesses coletivos, prejudicando o atendimento das demandas da sociedade civil, em especial dos usuários da política social. Além disso, é preciso considerar o avanço das políticas neoliberais no Brasil, as quais se apoiam na desvalorização da participação social (BRAVO, 2008, p. 56), atacando e desregulamentando também os espaços de democracia participativa. Portanto, a disparidade apresentada nos conselhos de políticas públicas acaba por atender a agenda neoliberal, a qual se pauta pela privatização dos serviços públicos e direcionando o fundo público para a inciativa privada, o que acaba por se reproduzir no âmbito dos conselhos, visto que estes representantes estão vinculados a essa perspectiva.

Nesse movimento reflexivo, vale destacar que os CMAS, que apresentam uma constituição paritária, também se configuram por relações fragilizadas nessas representações, dado que os representantes não governamentais nem sempre garantem a defesa dos interesses da classe trabalhadora, pois em grande medida, estão vinculados a outros grupos. Não obstante, como destaca Bravo (2008, p. 59) os conselhos de políticas públicas, mais pontualmente aqui os da assistência social a nível municipal, pela correlação de força e disputas de interesses presentes tornam-se espaços para cooptação da sociedade por parte do poder público.

Assim sendo, tendo em vista o conjunto de representações não governamentais que formam os Conselhos Municipais de Assistência Social, dos vinte e cinco (25) ${ }^{10}$ municípios, buscou-se identificar o perfil dessas representações a fim de reconhecer as relações de forças ali construídas. A constatação com a pesquisa documental é que há nitidamente um grande número de entidades religiosas e de associações compondo a representação não governamental dos CMAS. Caracterizando um perfil, em grande medida vinculado ao conservadorismo, como nos indica Iamamoto (2008, p. 199) "são espaços que podem ser capturados por aqueles que apostam na reiteração do conservantismo político, fazendo vicejar

\footnotetext{
${ }^{10}$ Do conjunto total - trinta e seis municípios -, onze destes não disponibilizaram as informações necessárias para que a análise fosse feita.
} 
as tradicionais práticas clientelistas, o cultivo do favor e da apropriação privada da coisa pública [...]”. Essas representações significam exatamente a reprodução de interesses particularistas que historicamente compõem e integram a política social brasileira.

As associações em geral aparecem integrando onze (11) CMAS enquanto representação não governamental, e quatorze (14) não configuram na constituição dos conselhos. Vejamos no gráfico a seguir essa representação:

Gráfico1: Associações em geral constituindo a representação não governamental dos Conselhos Municipais de Assistência Social (CMAS).

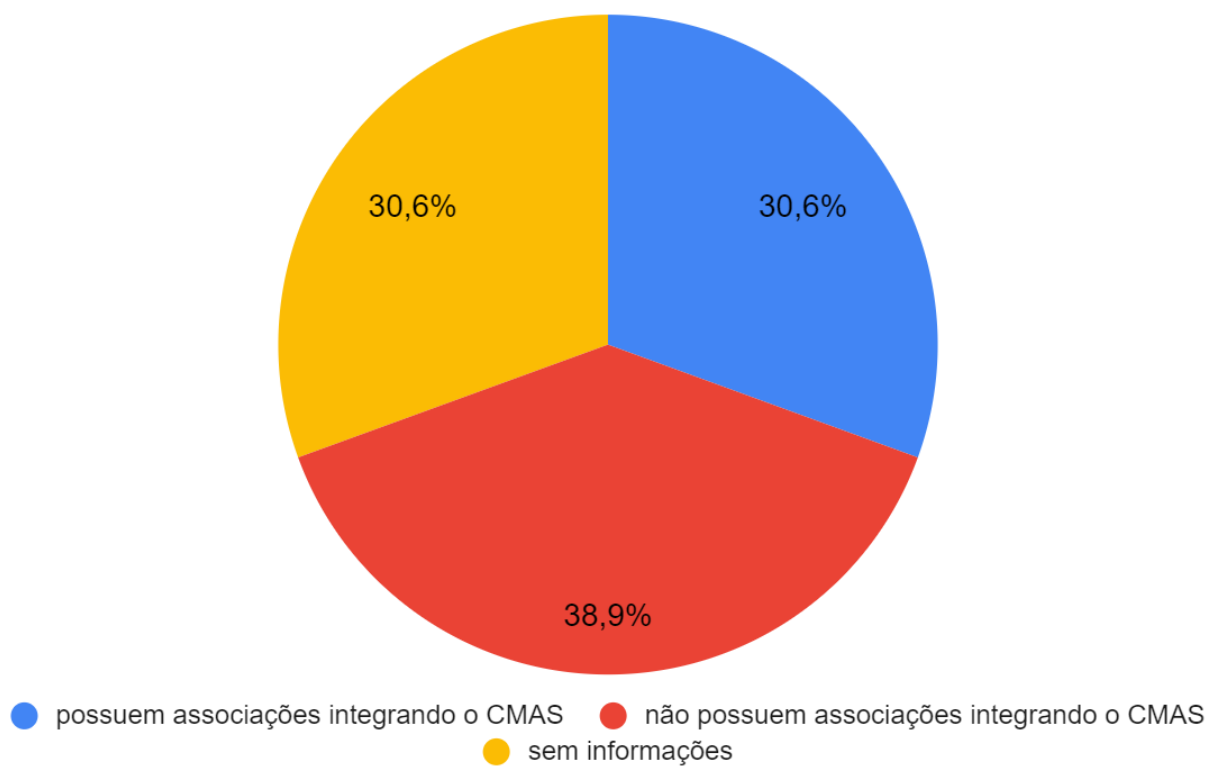

Fonte: Elaborado pelas autoras. (2021)

Do número de Associações que representam a sociedade civil, destaca-se a Associação de Pais e Amigos dos Excepcionais (APAE) que aparece na constituição de quinze (15) CMAS dos municípios pesquisados.

Ademais, as entidades religiosas integram treze (13) CMAS como parte da representação não governamental. A caraterística mais presente nestas entidades é o trabalho voluntário e a perspectiva da filantropia como atuação dentro da política de assistência social, demonstrando uma direção contrária do que se coloca na LOAS (1993), na PNAS (2004) e na instituição do SUAS. Essas formas de representação possibilitam o esvaziamento do potencial da sociedade civil, dado que se sobressaem interesses privados e não coletivos, tornando o espaço do controle social um mecanismo de burocracia e "democracia procedimental" (IAMAMOTO, 2008, p. 199). Dados que podemos observar no gráfico a seguir: 


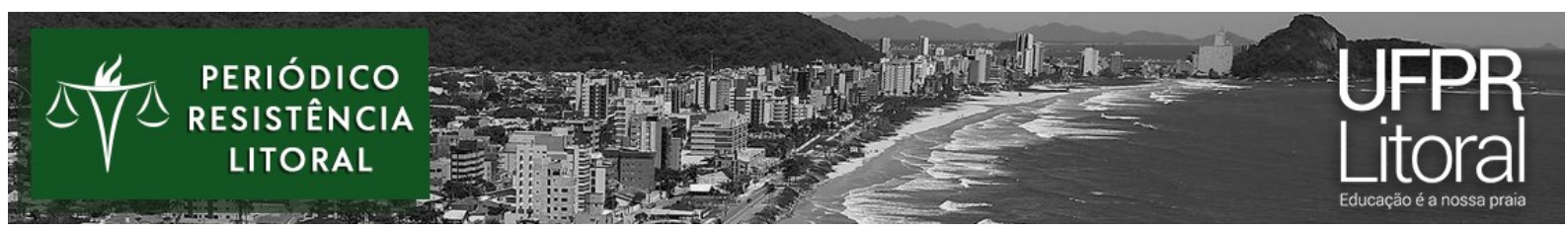

Gráfico 2: Entidades religiosas constituindo a representação não governamental dos Conselhos Municipais de Assistência Social (CMAS).

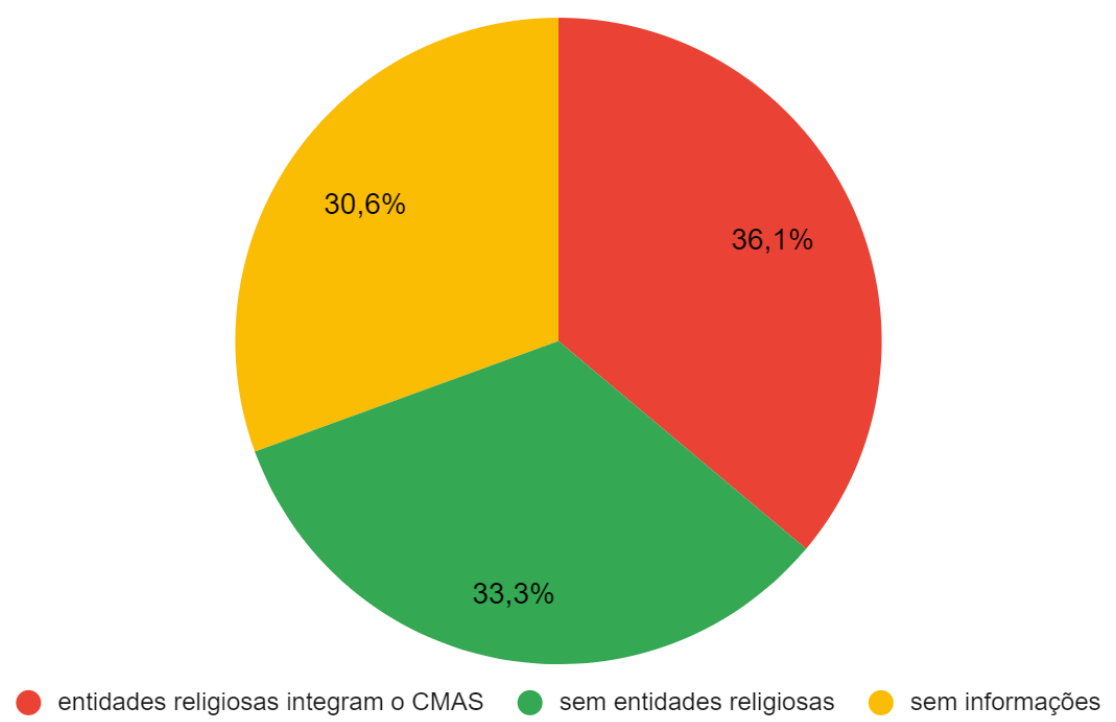

Fonte: Elaborado pelas autoras. (2021)

Diante desses dados, algumas questões podem ser provocadas e, entre elas, a fragilidade do segmento da sociedade civil para a defesa de suas demandas reais, além da atuação no varejo das políticas, especialmente pela manutenção de convênios para o financiamento de serviços, programas, projetos e benefícios, em detrimento do investimento em políticas públicas que se voltem à universalização de acesso e garantia de direitos a toda classe trabalhadora, como pontua MOREIRA (2008, p. 86).

As associações, como também as entidades religiosas ocupam um espaço significativo nos CMAS dos municípios e, nesse sentido, observa-se a frágil direção em que caminham as esferas que contam com a participação democrática da sociedade civil para construção da política pública, principalmente ao considerar que o formato dos conselhos de políticas sociais brasileiros se inclinam à elitização, havendo uma homogeneização dos conselheiros oriundos da parcela da população que possui renda, a qual muitos membros são do próprio funcionalismo público, limitando, assim, a representatividade e tornando os conselheiros representações elitizadas das organizações e até mesmo do próprio serviço público. (PARANÁ; FUKS; PERISSINOTTO, 2004 apud BRONSTEIN; FONTES; PIMENTA, 2017, p. 99).

Além dessa homogeneização das representações dos conselhos, é importante relembrar que, a partir dos anos 1990, com o avanço do neoliberalismo, tem-se uma ampliação da subjetividade da esfera pública, com o aumento da cultura do individualismo, privatista, da 


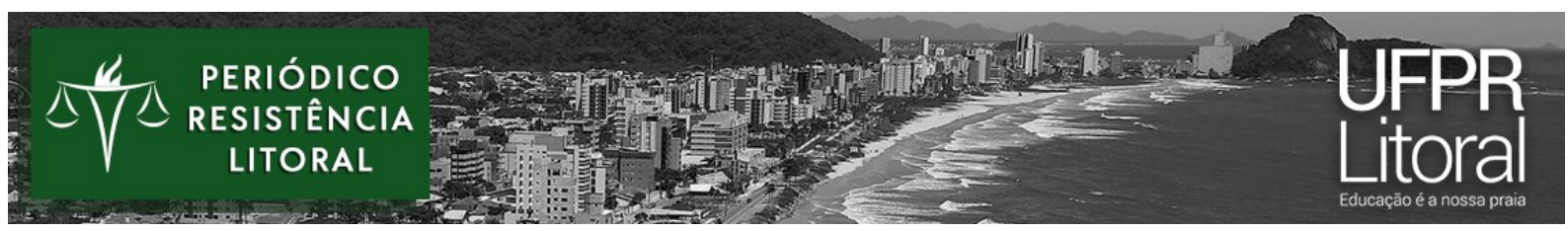

aparente desnecessidade do que é público, o que dificulta ainda mais a construção da esfera pública e a sua separação da esfera privada (RAICHELIS, 2008, p. 26). Partindo desse preceito, observa-se que a presença dessas associações e entidades prestadoras de serviço de assistência social é histórica, e tem um significativo peso no atendimento à população, possibilitando a complementação ou até mesmo a substituição das ações do Estado, conforme (CUNHA 2010, p. 124 apud SANTOS, 2016). Destaca-se, ainda, a Resolução CNAS n 11, de 23 de setembro de 2015, que caracteriza os usuários, seus direitos e a participação desses na Política de Assistência Social e no SUAS e, cujo objetivo é evitar a presença das/os trabalhadores ou representantes das entidades privadas, ocupando as vagas de conselheiros em nome dos usuários (BRASIL, 2015). Raichelis (2008, p. 28-29) aponta o quanto à reorientação das políticas públicas estão carregadas de uma ótica gerencial, enfatizando as parcerias públicoprivado, baseando-se na gestão empresarial de recursos humanos, materiais e financeiros e, nesse contexto, expandindo o associativismo civil, conjunto amplo de entidades sociais: ONGs, organizações empresariais, associações comunitárias, que disputam o fundo público na intenção de executarem os seus programas, projetos e serviços.

Para complementar o cenário de composição dos CMAS, destaca-se a baixa presença de movimentos sociais ou segmentos da sociedade organizada. Dessa forma, considerando os vinte e cinco (25) municípios em que se acessou as legislações dos CMAS, apenas três (03) municípios possuem a participação de movimentos sociais ou organização dos trabalhadores, os outros vinte e dois (22) não apresentam nenhuma representação nesse sentido. Assim temos o seguinte gráfico: 


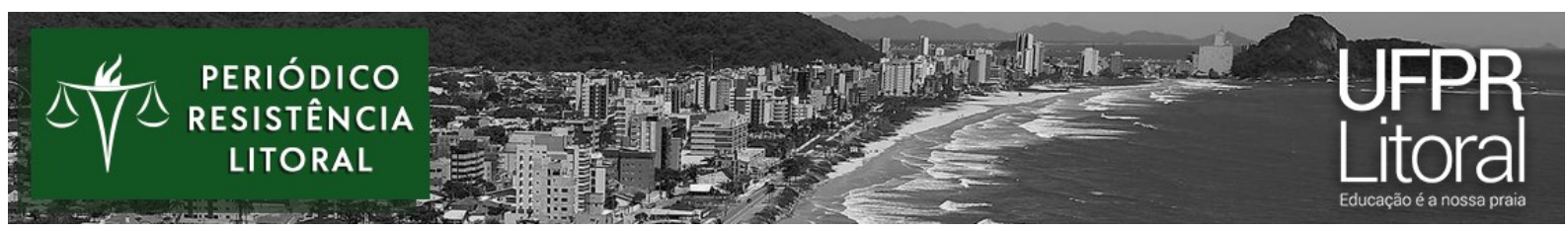

Gráfico 3: Movimentos Sociais/organização da classe trabalhadora que constituem a representação não governamental dos Conselhos Municipais de Assistência Social (CMAS).

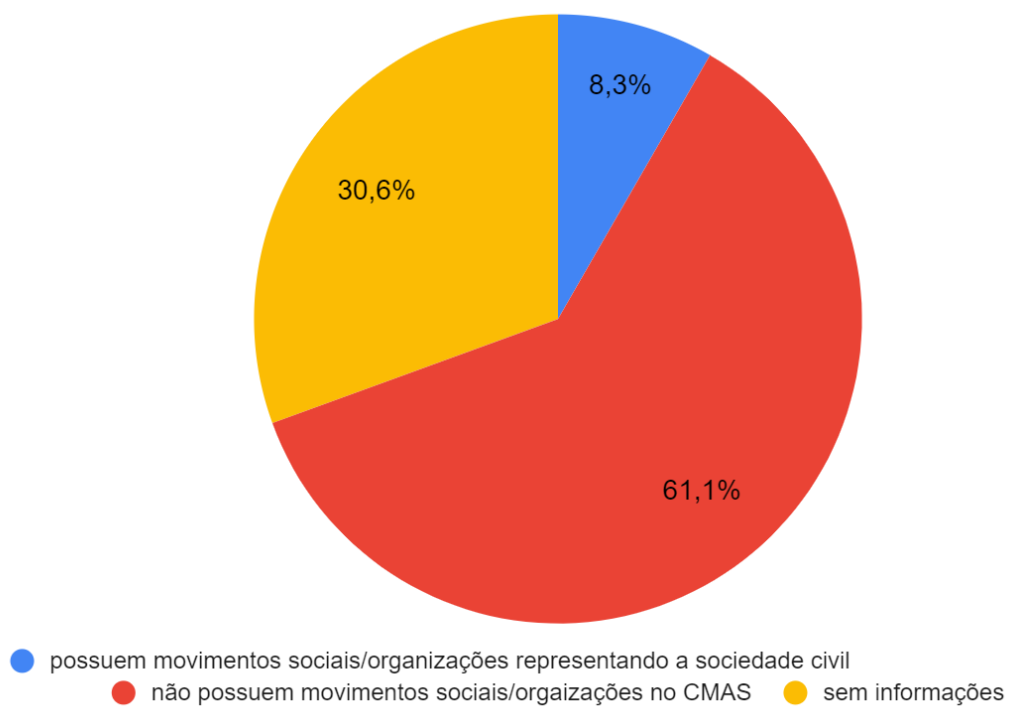

Fonte: Elaborado pelas autoras. (2021)

Evidentemente, tem-se uma diminuta presença de Movimentos Sociais ou qualquer organização classista nos espaços de participação democrática referente às políticas públicas. Diante dessa constatação, questiona-se a proveniência dessa ausência nas esferas participativas, para Bronstein, Fontes e Pimenta (2017, p. 99) “os conselhos municipais de políticas sociais, vistos enquanto órgãos de administração pública e não enquanto instrumentos da sociedade civil pode dificultar o relacionamento e a confiança entre as partes e, consequentemente, acabar limitando a participação social". Para além disso, Raichelis (2008, p. 24) indica que, "junto à agenda neoliberal e toda a cultura individualista envolta, há a desvalorização do senso crítico agindo em conjunto para o entendimento da questão social por meio dos discursos solidários, filantrópicos". É nesse sentido que a ideia de participação popular foi ressignificada, passando a "ser compreendida como uma participação solidária, despolitizando o significado concreto da coletivização dessa participação da sociedade na esfera pública", compreendendo de forma mais voluntária e individualista (ROCHA, 2008, p. 145). Os movimentos sociais, nesse mesmo contexto, também sofrem diante da ascensão das políticas neoliberais, sendo criminalizados, enfraquecidos e cada vez mais atacados pelas políticas de governo, especialmente na atualidade.

Ressalta-se que os conselhos de políticas públicas têm potencial para serem espaços de participação democrática, especialmente com a inserção dos movimentos sociais, estabelecendo coletivamente uma direção para a disputa de interesses inerentes à classe trabalhadora, 
fortalecendo a articulação com as bases e a participação democrática (BRAVO, 2008, p. 58). Além do mais, essa pouca integração dos movimentos sociais ou da classe trabalhadora organizada demonstra o enfraquecimento da função desses conselhos, tendo em vista que as representações não governamentais acabam categorizando os interesses disputados e, nesse sentido, cabe compreender quem são essas representações e o que elas defendem nesse espaço, considerando a atribuição e o compromisso que assume um Conselho Municipal de Assistência Social - bem como qualquer outro conselho de política pública.

Observa-se, em todos esses dados e gráficos, que há muito ainda que avançar para que se possa mostrar efetividade na consolidação desses CMAS enquanto instrumentos que se promovam a participação democrática da sociedade civil em assuntos que a interessam fundamentalmente. A direção a ser assumida nos espaços do controle social deve indicar "uma permanente articulação política no âmbito da sociedade civil organizada, para contribuir na definição dessas representações e nas propostas e estratégias comuns ao campo democrático" (IAMAMOTO, 2008, p. 199, grifo nosso). As condições aqui apontadas, portanto, colocam em questão diversos elementos e sujeitos, os quais estão diretamente atuando e estruturando os espaços de participação democrática como os conselhos de políticas públicas.

\section{CONSIDERAÇÕES FINAIS}

É sabido que a Constituição Federal brasileira promulgada em 1988 apresentou diversos avanços institucionais e democráticos frente à pressão política que desenhava o cenário político da época. Com o intuito de acalmar e desmobilizar a organização da classe trabalhadora, muitas demandas foram incorporadas pela Carta Magna através da Constituinte e, dentre essas demandas, pontua-se a necessidade de espaços democráticos, com a participação da sociedade civil. Nessa perspectiva, aponta-se que os conselhos de políticas públicas foram instituídos na década de 1990 concomitante às políticas neoliberais, o que resultou em experiências que se afastam do que realmente se previu nas legislações. O controle social implementado conta com representações governamentais e não governamentais em seu interior - geralmente paritárias , resultando em um espaço deliberativo, político e de disputa de interesses. Ao longo da história de implantação dos conselhos, se configurou uma tendência de se apresentar como mecanismos que legitimam o poder já dominante do Estado, tendo em vista que não há hegemonia nos interesses das representações de conselheiros da sociedade civil (MACHADO, 2015, p. 61). 


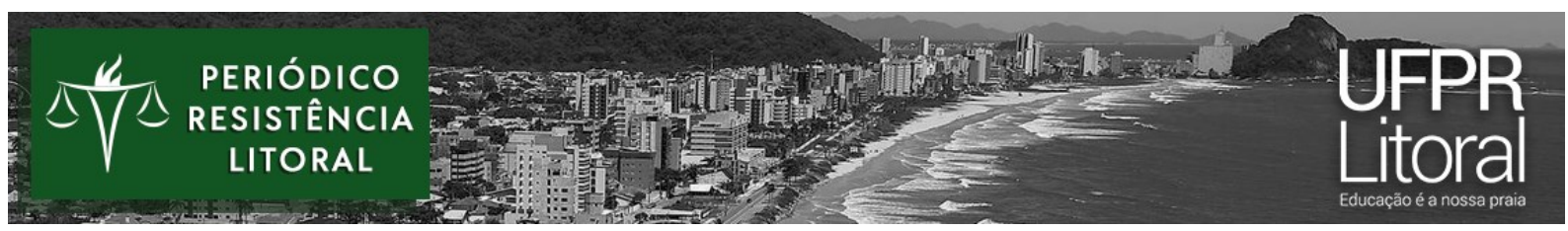

Estruturados nesse cenário de disputa, os Conselhos Municipais de Assistência Social, constituídos mais especificamente a partir da Lei Orgânica da Assistência Social, como também com o Sistema Único de Assistência Social e a Política Nacional de Assistência Social, enquadram-se na contraditória relação Estado-sociedade civil, que é demandada a partir do debate da política de assistência social.

Os CMAS apresentados nessa pesquisa documental demonstram o extenso caminho a ser percorrido para que a gestão democrática seja efetivada no intuito de cumprir e privilegiar a universalização dos direitos da sociedade civil, considerando que há ausência de informações básicas acerca dos CMAS nos municípios, bem como há falta de paridade e as representações não governamentais, majoritariamente, constituem-se em associações e entidades religiosas, desviando o caráter público da política de assistência social, reiterando perspectivas clientelistas e conservantistas. Conforme Faria e Ribeiro (2010, p. 62-63 apud SANTOS, 2016),

Uma vez que os desenhos institucionais dos conselhos municipais de políticas públicas não são neutros, suas escolas e variações, tais como quem participa ou como são recrutados, incidem diretamente sobre a atuação do colegiado, produzindo diversas consequências para os resultados da participação social.

É preciso pontuar que a paridade entre as representações governamentais e não governamentais não asseguram o equilíbrio das relações sociais dentro dos conselhos, bem como não garantem a defesa dos direitos e interesses da classe trabalhadora, isto é, outros fatores podem influenciar nesse espaço de disputa política. Além disso, a historicidade brasileira - mais especificamente a partir da década de 1970 até a década de 1990 - assinala a participação social da população na efervescência política, atuando, majoritariamente, a partir de sua organização orgânica e não pelas vias oficiais. Nesse sentido, a relação entre a sociedade civil e o Estado nunca se deu baseada na confiança ${ }^{11}$, e sim na pressão popular. Por outro lado, o avanço da agenda neoliberal, a partir da década de 1990, propiciou também uma forma de ver o mundo pautada no individualismo, criando um sujeito neoliberal, para além de um modelo econômico e, consequentemente, as políticas públicas perdem seu caráter concreto pautado em uma sociedade de classes e perpetuam-se de maneira paternalista, como uma concessão estatal.

\footnotetext{
${ }^{11}$ Bronstein, Fontes e Pimenta (2017, p. 98) destacam que o impacto na confiança do cidadão comum na gestão pública municipal a partir da sociedade civil organizada nos Conselhos Municipais não ocorre, considerando que as discussões são praticamente restritas ao interior desses espaços, existem poucas chances dessas alcançarem o cidadão comum, tanto pela falta de acesso à informação, pela falta de interesse na participação, os cidadãos possuem poucas chances de participarem efetivamente dos conselhos.
} 


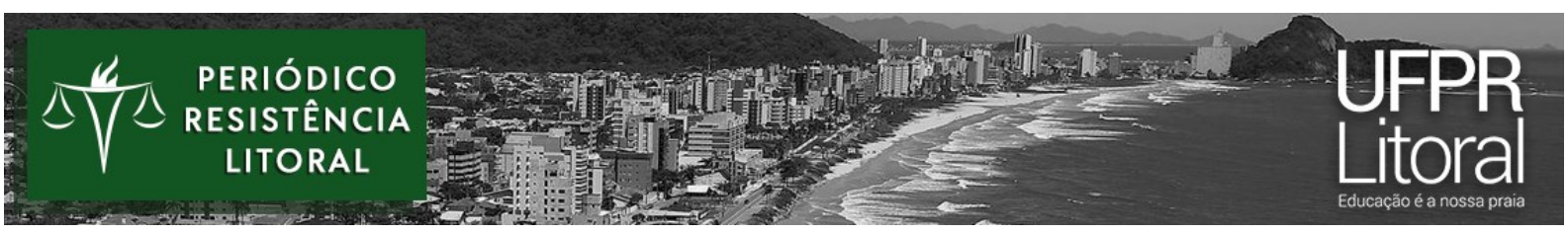

Fruto da falta de confiança no Estado por parte da sociedade civil e da cultura neoliberal e individualista proposta pelas políticas neoliberais, a relação que engloba a esfera estatal e o corpo social é completamente debilitada e instável. Os Conselhos Municipais de Assistência Social - e todos os outros -, na qualidade de existir exatamente no bojo dessa relação, não se manifestam de forma diferente, expressando, assim, os formatos e as proporções em que se encontram condicionadas às políticas sociais e suas deliberações.

Considerando as informações coletadas e o perfil identificado das representações da sociedade civil e a relação histórica estabelecida com o Estado, no âmbito dos conselhos de assistência social, é possível afirmar que os grupos sociais ali inseridos se situam ainda "no momento econômico-corporativo", em que a prioridade é o dever solidário, mas sem ultrapassar os limites de seus próprios interesses. Não há a criação de uma "consciência de solidariedade de interesses de todos", assim, permanecem no campo dos "interesses corporativos de grupos meramente econômicos" (GRAMSCI, 2011, p. 41).

Desde a constituição dos conselhos de políticas sociais, enfrentam-se inúmeros obstáculos para que sua proposta constitucional seja efetivada, principalmente pontuando a participação da sociedade civil. Condicionados aos movimentos neoliberais, os Conselhos Municipais de Assistência Social são atravessados pelas contradições e reveses impostos e, como observado, submetem-se às estratégias exigidas de controle da esfera estatal, mantendo a assistência social domesticada ao arquétipo neoliberal.

Por fim, cabe refletir e repensar o espaço dos CMAS e toda sua importância diante das contrarreformas e destituições de direitos que estão ocorrendo na atual política de governo, atentando-se, principalmente, na emergência de fortalecer a participação da classe trabalhadora organizada, que se mostra quase ausente atualmente, como também fortificar a mediação com a sociedade civil orgânica, com os usuários da política de assistência social, "assim é fundamental estimular inserções sociais que contenham potencialidades de democratizar a vida em sociedade" (IAMAMOTO, 2008, p. 199), buscando consolidar o controle social e fazer jus aos espaços democráticos existentes.

\section{REFERÊNCIAS}

ALMEIDA, Carla; TATAGIBA, Luciana. Os Conselhos Gestores sob o Crivo da Política: balanços e perspectivas. Revista Serviço Social e Sociedade, São Paulo: Cortez, nº 109, janmar, p. 68-92, 2012. 


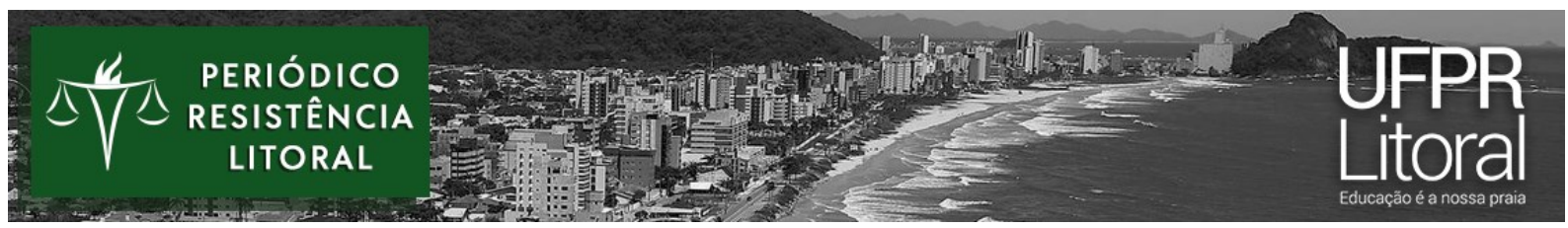

BEHRING, Elaine R. O Plano Plurianual do Governo Lula: um Brasil de todos? In. Serviço Social, Política Social e Trabalho: desafios e perspectivas para o século XXI. FREIRE, L; FREIRE, S; CASTRO, A. T. B, 2a ed. São Paulo: Cortez Editora, 2008.

BOSCHETTI, Ivanete. Os custos da crise para a política social. In. BOSCHETTI, Ivanete et al (Orgs.), Capitalismo em Crise: política social e direitos. São Paulo: Cortez Editora, 2010.

BRASIL, Presidência da República. Casa Civil. Subchefia para Assuntos Jurídicos. Constituição Federal do Brasil de 05 de outubro de 1988. Brasília: Senado Federal, 1988. Disponível em: http://www.planalto.gov.br/ccivil_03/constituicao/constituicao.htm

BRASIL, Presidência da República. Casa Civil. Subchefia para Assuntos Jurídicos. Lei no 8.742 de 7 de dezembro de 1993. Lei Orgânica da Assistência Social. Brasília, 1993. Disponível em: http://www.planalto.gov.br/ccivil 03/leis/18742.htm

BRASIL, Ministério do Desenvolvimento Social e Combate à Fome. Resolução $n^{0} 145$ de 15 de outubro, Política Nacional de Assistência Social, Brasília, 2004. Disponível em: https://www.mds.gov.br/webarquivos/publicacao/assistencia_social/Normativas/PNAS2004.p $\underline{\mathrm{df}}$

BRASIL, Presidência da República. Casa Civil. Subchefia para Assuntos Jurídicos. Lei no 12.527 de 18 de novembro de 2011. Lei de Acesso à Informação. Brasília, 2011. Disponível em: http://www.planalto.gov.br/ccivil 03/ ato2011-2014/2011/lei/112527.htm

BRASIL, Conselho Nacional de Assistência Social. Resolução no 11 de 23 de setembro de 2015. Caracteriza os usuários da Política de Assistência Social. Brasília, 2015. Disponível em: https://www.in.gov.br/materia/-/asset publisher/Kujrw0TZC2Mb/content/id/32870261

BRASIL, Presidência da República. Casa Civil. Subchefia para Assuntos Jurídicos. Emenda Constitucional $\mathrm{n}^{\circ} 95$ de 15 de dezembro de 2016. Novo Regime Fiscal. Brasília. 2016. Disponível em: http://www.planalto.gov.br/ccivil 03/constituicao/emendas/emc/emc95.htm

BRASIL, Presidência da República. Casa Civil. Subchefia para Assuntos Jurídicos. Emenda Constitucional no 103 de 12 de novembro de 2019. Altera o Sistema de Previdência Social. Brasília, $2019 . \quad$ Disponível em: http://www.planalto.gov.br/ccivil_03/constituicao/emendas/emc/emc103.htm

BRAVO, Maria Inês. Potencialização das Representações do Conjunto CFESS/CRESS nos Conselhos de Políticas e de Direitos. In: Conselho Federal de Serviço Social. O Controle Social e a Consolidação do Estado Democrático de Direito. Brasília: Mais Gráfica Editora, p. 53-67, 2008.

BRAVO, Maria I. S; CORREIA, Valéria C. Desafios do Controle Social na Atualidade. Revista Serviço Social e Sociedade, São Paulo: Cortez, n. 109, p. 126-150, jan./mar. 2012. 


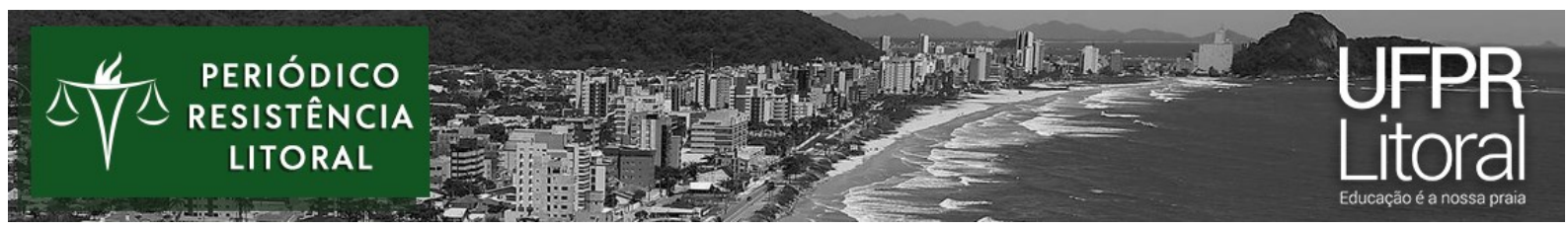

BRONSTEIN, Michelle Muniz; FONTES F, Joaquim Rubens; PIMENTA, Gabriel Alves. Organização dos Conselhos Municipais: governança e participação da sociedade civil. Interações, Campo Grande, MS, v. 8, n. 1, p. 89-102, jan./mar. 2017.

FERRAZ, Ana T; RABELO, Desirée; HERKENHOFF, Maria B. O Debate sobre o Controle Social da Política de Assistência Social entre 1985 e 2008. Revista Temporalis. Brasília: ABEPSS, Ano X, p. 133-149, jan./jun. 2010.

GRAMSCI, Antonio. Cartas do Cárcere. Tradução: Luiz Sérgio Henrique e Carlos Nelson Coutinho (Orgs.). Rio de Janeiro: Civilização Brasileira, p. 82-85, 2005. v. 02.

GRAMSCI, Antonio. Cadernos do Cárcere: Os intelectuais. O Princípio Educativo. Jornalismo. $5^{\text {a }}$ ed. Tradução: Carlos Nelson Coutinho. Rio de Janeiro: Civilização Brasileira, 2010. v. 02.

GRAMSCI, Antonio. Cadernos do Cárcere: Maquiavel notas sobre o estado e a política. $4^{\mathrm{a}}$ ed. Tradução: Luiz S. Henrique, Marco Aurélio Nogueira e Carlos Nelson Coutinho (Org.). Rio de Janeiro: Civilização Brasileira, 2011. v. 03.

IAMAMOTO, Marilda e CARVALHO, Raul de. Relações Sociais e Serviço Social no Brasil: esboço de uma interpretação histórico-metodológica, $8^{a}$ ed., São Paulo: Cortez Editora, 1991.

IAMAMOTO, Marilda V. Serviço Social em Tempo de Capital Fetiche: capital financeiro, trabalho e questão social, $3^{\text {a }}$ ed., São Paulo: Cortez Editora, 2008.

IAMAMOTO, Marilda.; YAZBEK, Maria C. (Orgs.). Serviço Social na História: América Latina, África e Europa, São Paulo: Editora Cortez, 2019.

MACHADO, Cristiane Ferrari Canez. Os Assistentes Sociais nos Conselhos de Assistência Social como representantes do gestor. 2015. 203 f. Dissertação (Mestrado) - Programa de PósGraduação em Serviço Social, Universidade Federal de Santa Catarina, Florianópolis, 2015.

MOREIRA, Marinete Cordeiro. Potencialização das Representações do Conjunto CFESS/CRESS nos Conselhos de Políticas e de Direitos. In: Conselho Federal de Serviço Social. O Controle Social e a Consolidação do Estado Democrático de Direito. Brasília: Mais Gráfica Editora, p. 68-88, 2008.

NETTO, José Paulo. Capitalismo Monopolista e Serviço Social. $8^{a}$ ed. São Paulo: Cortez Editora, 2011.

RAICHELIS, Raquel. O Controle Social Democrático na Gestão e Orçamento Público 20 anos depois. In: Rio Grande Do Norte. Conselho Federal De Serviço Social. O Controle Social e a Consolidação do Estado Democrático de Direito. Brasília: Mais Gráfica Editora, p. 19-31, 2008.

RAICHELIS, Raquel. Esfera Pública e Conselhos de Assistência Social: caminhos da construção democrática, $7^{\mathrm{a}}$ ed., São Paulo: Cortez Editora, 2015. 


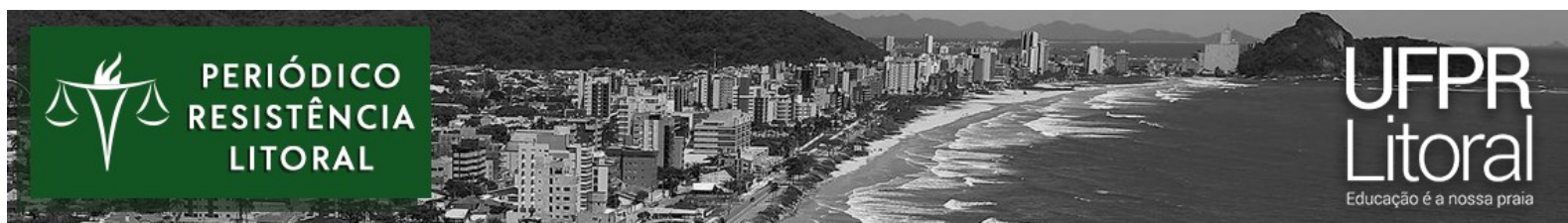

ROCHA, Enid. A Constituição cidadã e a institucionalização dos espaços de participação social: avanços e desafios. 20 anos da constituição cidadã: avaliação e desafio da seguridade social, ANFIP, Brasília, 2008.

SANTOS, André Yokowo dos. Paridade nos Conselhos Municipais de Assistência Social. 2016. 34 f. TCC (Graduação) - Curso de Especialização em Gestão Pública, Enap, Brasília, 2016. Disponível em: http://www.planalto.gov.br/ccivil_03/leis/18742.htm. 